\title{
Aristotle and the Tensions between Politics and Economy
}

\author{
Dr. Hernán Borisonik* \\ Universidad de Buenos Aires (Instituto de Investigaciones Gino Germani), CONICET (National Scientific and Technical Research \\ Council), Buenos Aires, Argentina \\ *Corresponding author: hborisonik@sociales.uba.ar
}

Received July 15, 2013; Revised August 02, 2013; Accepted January 06, 2014

\begin{abstract}
As presented by Georgio Agamben, the notion of sacer (sacred) appears to be an unavoidable element to analyze the structure of occidental political thought from its very beginning up to the present time. Such interpretation throws new ideas on an essential question: the relationship between politics and economy in Aristotle, the one who had the most complete political project of the ancient world. In that sense, money has a privileged place to deepen Aristotle's thought. As much in the critique of accumulation and the usury that takes place in his analysis of chrematistics (Politics 1256b-1258a) as well as in the need to consecrate ill-gotten gains in democracies (Politics 1320a), it is clear that money appears in crucial points for defining the relationship between sacred and profane, between politics and the economy. The attempt of this communication will be, then, to make a concrete study of the Aristotelian passages previously mentioned along with commentary on some complementary notes taken from the Nicomaquean Ethics and the Constitution of Athens and to integrate them with Agamben's explanation of the Homo Sacer. For that reason, categories as 'sacred', 'use', and 'exclusion' will be fundamental for this study.
\end{abstract}

Keywords: politics, economy, sacredness, aristotle

Cite This Article: Dr. Hernán Borisonik, “Aristotle and the Tensions between Politics and Economy." Journal of Finance and Economics 2, no. 1 (2014): 1-6. doi: 10.12691/jfe-2-1-1.

\section{Introduction}

In this article we will make an analysis the economic and political Aristotelian thinking from a perspective that assumes an intimate bond with the notion of the sacred. We will identify this sense of the Aristotelian writings through a detailed and in-depth textual analysis.

We will pick up the thread of Giorgio Agamben's Homo Sacer's first section [1]. This path has been partially left out in [2], where oikonomía is considered in reference to the Christian medieval conception, and thus, Agamben's focus is on Metaphysics.

Even though, as Agamben argues in [1], Politics and Metaphysics are consistent with each other, it is significant to take up Politics again. While in Metaphysics the immutable phýsis is the object of study, it is in Politics where Aristotle examines contingent human activity. This is the reason why Politics and Ethics allow us to elaborate this study.

\section{Objectives}

We would like to point out that the purpose of this presentation is to consider some research outcomes meant to be continued and deepen in future studies. In the same perspective as Agamben's, we intend to trace the elements of the Aristotelian analysis that enable the study of the particular way in which occidental politics appears as heir to the specific ways of unavailability outlined in the
Greek-Roman world; that is, of what institutes itself as banned from human use.

In this regard, we do not intend to present a closed interpretation of Aristotle's thought, but to read carefully some specific passages in which this trend of thought becomes visible. This statement is due to the fact that the various understandings of Aristotle's work as a finished system have done nothing but expose the multiplicity expressed in a fragmentary and incomplete corpus, which, in addition, was conceived by Aristotle himself as a group of lessons. Moreover, different linguistic and ideological traditions have cut trough this collection. As a matter of fact, short after Aristotle died the philosophical style fostered by both Plato and himself was abandoned, and their 'successors' veered towards scepticism and even a certain scientism. In the Middle Ages, Aristotle's Politics in its original language was completely unknown until the 13th Century A.C. Although there were some translations, it is remarkable that even Thomas Aquinas, such a fundamental source for the modern interpretative tradition, never gained access to the original Greek texts.

As for us, we will go over some fundamental Aristotelian passages in order to understand his economic notions and to relate them to his political conception. Besides, we intend to fully grasp the relationship between the economic and the sacred.

\section{Methods}

The methodology concerning this paper's goals will be eminently theoretical. Some authors and text will be read 
from an exegetical and hermeneutical point of view. In regard of that, there is not going to be empirical data in this study, although it will be possible to find historical information.

First of all we will take into consideration Émile Benveniste's approach to the vocabulary of the IndoEuropean institutions, and the paradigmatic case of Aristotle's criticism to chrematistic as well. At the same time, it should be noted that Agamben's conceptualization of sacredness will be the leading perspective encompassing this presentation. Besides that, some historical facts will be put into consideration, mostly to understand Aristotelian thought.

\section{Discussion}

To begin with, we will take into account the results at which Émile Benveniste has arrived in his thorough study on Le Vocabularie des Institutions Indo-Européenes. In the first place, through a very detailed analysis, the author argues that the notions of profit, property and possession were independent from actual goods. They were abstract conceptions which bore no relation to what was own and could be used in different situations. At the same time, Benveniste shows that while the present meaning of these concepts is undoubtedly linked to economy and commerce, in its origin the meaning had strong religious and juridical connotations. This is why he states in [3] (in page 121) that “tout le vieux droit n'est qu'un domaine particulier regí par des pratiques et des règles qui baignent encore dans la mystique" ("all the ancient right is nothing but a particular domain regulated by practices and rules that are still immersed in mysticism”).

In this regard, the exchange is understood as a circuit of gifts rather than exchange with profit motive in mind. In fact, the terms "give" and "take", “distribute" and "receive", were intimately linked. In this respect, the Greek terms dapanau and dapané denoted religious and very lavish expenses that implied exhibition and destruction of wealth in pursuit of the community. It is in this sense that Aristotle in [4] conceived virtues such as liberality and magnificence (we will deal with these concepts later on). Only in Rome these terms began to point to burden, to damage, hence the derivations of damnare (Latin for dapanau) as damage.

In addition, Benveniste shows the importance of the gift (in Greek: dorón, to give for free, expecting nothing in return) and the distribution. Both notions highlight the Greek conception of friendship, not as a private and sentimental liaison but as reciprocity, as exchange that links and compels (we will also deal with this notions later on).

A fourth point of interest in Benveniste's study is that all actions which derived in economic categories did so from relations among men or between men and gods. They did not derive from the interaction with goods, nor due to material needs. A possible explanation is to be found in the absence of an ancient conception of limited goods. Back then, the original meaning of value (as price) was tied to individual merit; buying had its roots in the release of prisoners; selling in the gods-votive offerings; renting in the managing of mercenary troops; credit in the belief of the divine; etc. In short, ancient commercial conceptions clearly have strong religious and juridical overtones, and men, not goods, were originally subjected to retail trade.

As regards commerce, Benveniste discloses that there were two clearly-defined activities in the Indo-European view of the world (unlike other cultures where the entire population was engaged in commercial activity). On the one hand, those who worked the land and took the farming surpluses to a common place where it was sold or exchanged for other goods or money were not engaged in a commercial activity. As Benveniste puts it, that was not commerce itself. But on the other hand, proper commerce was indeed individual: the merchant placed goods in circulation. The words for "commerce", "goods" and "price" bore no relation to the words used for "buying" and "selling" which had religious connotation.

In this same sense, the word askholía (Greek for "business") meant a lack of leisure, of occupation and, at the same time, a lack of preoccupation. Therefore, its sense was not as sharply commercial as the Latin negotium. In fact, commercial matters did not have a name which defined them positively or specifically, thus it can be observed that they were not an established and traditional activity but a marginal occupation. Commerce was simply defined as "having to do something" or "being busy”.

A cause of such situation could be found in the fact that, in Greece, commerce was not a citizens' business; it was an inferiors' matter. To prove so, it is enough to address the Aristotelian texts and realize that the word used for commerce, kapelikós, derived from kapelos, which referred to the bargainers and had a clear pejorative connotation. Wholesale demanded new terms, such as émporos (wholesale and maritime trader), which had a clearer reference to the maritime voyage than to the commercial activity itself. Consequently, we can say with Benveniste, that in spite of the fact that there was a normal circuit of exchange, where goods were given in order to obtain something in return, there was also another one, an underlying circuit. That was the circuit of benefit and gratitude, where goods were given without expecting payment and offerings were made to thank.

As it can be observed, there was a strong religious charge in Greek economic conceptions. This is why we should inquire into the meaning of the sacredness in that society.

The first lesson learnt from Benveniste on this respect is the conceptual opposition between the human and the divine. This opposition rests on the basis of the ancient paradigm as well as on the foundations of modern age (only in a slier and more sophisticated way).

We should examine three Greek terms for the purposes of this presentation. Firstly, hierós, which in ancient Greek meant "strong" or "full of strength by divine influence", and then "sacred" derived from this notion. It was always an epithet of veneration and was connected to the divine. Secondly, hósios referred to the sacred as well, but its profound sense was "what was appointed to human relations by divine law”. Whereas hierós belonged to the gods, hósios represented the human procedures laid down by the gods. With the passing of time, hierós derived to "banned from the use of men" and hósios to "permitted or enjoined by the gods". Eventually, hierós conveyed as "sacred" while hósios as "profane, accessible to men, not sacred”. 
Finally, hágios referred to the things which must be defended against all forms of violation. It was a negative concept (neither profane nor divine). Hágios designated the mechanism through which the transfer between the human and the divine happened. Then, hierós was "full of sacred power and roughness" (what was clearly opposed to the human and was absolutely sacred) and hágios, "those things which a person could not come into contact with" (what required an operation to leave the sphere of human action).

As a result, the sacred (whether it was absolute or relative, natural or mediated by an operation) was defined by a prohibition of common use. It was a way to make things, places or people unavailable and it was invariably accompanied by a prescription.

Thanks to Benveniste's philological studies we can understand that there was a dual logic (between sacred and profane) in Aristotle's Greece. This logic determined the things that could be used by men and those that had to remain without use, set aside. Because of this logic and of Benveniste's find that every economic notion comes from religious and juridical concepts, we can see that there is a structure that cuts through the entire occidental culture; and, of course, through the Aristotelian considerations on money and economy.

It should be noted that an explanation of linguistic, traditional and temporal mediations as well as the examination of how accurately Aristotle's ideas have been read, exceed by far the possibilities of this presentation. Suffice it to say that the modern theorists who have marked our own economic conception reintroduce some Aristotelian ideas on the basis of their own categories. In all fairness, Aristotelian texts are usually considered the first analytical contribution to political economy.

The main passages are found in Nicomaquean Ethics V, 5 and in Politics I, 8-10. Such chapters are typically regarded as lacking in coherence and as nothing much than an expression of anti-commercial stances. Few parts of the Aristotelian corpus have been taken in such low esteem. In this regard, it is important to remember that in the 4th Century B.C., Athens developed to a significant level the production and circulation of goods as well as the exchange of goods. Aristotle addressed this specific historical development.

We must examine now some historical facts that, along with the previously presented conceptions, constitute the Aristotelian work's perspective.

The Greek society was going through a period of great change throughout Aristotle's lifetime. The Stagirite indirectly gave an account of this process by condemning certain elements which were undermining the already declining political organization.

As Karl Polanyi in [5] puts it, Aristotle found himself in the exact time and place of the first and incipient appearance of a commercial market with comparable characteristics to the modern market. This is why Aristotle is a privileged actor in the comprehension of such phenomena.

From the 5th Century B.C. on, with the advent of democracy, the Athenian citizenship had begun to become more hierarchical. It was then when the non-citizen appeared in front of the titular holder of rights, the citizen; and between both of them, the free man without property that needed to work to be able to survive.
During this same period, Athens began to impose its currency on the whole Greek territory.

Halfway through the 5th Century B.C., such polis demanded the payment of taxes in cash (not in ships, men or species) of the rest of the cities. Likewise, Athens asked the rich citizen for donation of theatres and ship equipment and started to establish a sort of tax system for inhabitants and for transactions on Athenian soil. The passage from bartering and self-sufficiency to the extended use of currency arose in cities with access to the sea, especially in Athens which functioned as cultural and economic capital of the Greek confederation.

Faced with such situation, Aristotle described numerous measures which had been adopted in order to prevent the money from becoming a problem in the continuity of the political organization. Most of the references in connection with these measures are found in The Athenian Constitution, a treaty which recounts the story of the city and the conditions in which the Athenians lived during Aristotle's lifetime. In these passages, the most important ways to preserve the order were related to the search for a curb on the enrichment of the men who were to govern the polis.

The issue of money appears in the background of all these measures. It is clear that the cash accumulation entailed (for the Greek way of life) the inrush of individuality against community. That irruption was understood as a problem to be regulated.

However, ostracism was the most important measures of all. It was used to punish the citizens who disrupted social life by banishing them from the polis. Its purpose tended to suppress those who were eminent for an uncommon degree of virtue, hindering the path towards tyranny. Ostracism was, above all, a safety measure for democracies which "are held to pursue equality most, and so they ostracize those held to be outstandingly powerful (whether because of their wealth, their many friends, or any other source of political power), banishing them from the polis for fixed periods of time", as Aristotle shows in [6].

For a clear example, let's take the case that Aristotle mentions in paragraph 1259a [6], of a man who "used some money that had been lent to him to buy up all the iron from the foundries, and later, when the merchants came from their warehouses to buy iron, he was the only seller. He did not increase his prices exorbitantly and yet he turned his fifty silver talents into one hundred and fifty. When Dionysius heard about this, he told the man to take his wealth out, but to remain in Syracuse no longer”.

It can be observed that exile shows one of the ways in which the Greeks had incorporated the Indo-European logic to their law as well as the strong sacred mark on that penalization. There are two direct references to the divine in the brief theoretical section devoted, in [6] to the issue of ostracism (paragraphs 1284a-b). In the first place, the outstanding man is mentioned as "a God among men", thus to treat him as an equal would be the same as to "desire to share the power of Zeus and to govern him". It does not seem by chance that Aristotle expresses the resemblance between these men and the gods, being both subjects of different law. This structure of thinking places the ostracized outside the human law, therefore excluded from the political community.

Aristotle's Greece was going through a growing crisis. New social practices in which acquisition and 
accumulation of money were important appeared along with the fall of the traditional organization of the family oikonomía, towards embryonic forms of urban economy based on import-export commerce.

The tensions between the different groups involved in politics became noticeable. So did the expressions of social antagonism and erosion of harmony among the parts of the community. These facts caused anxiety for the inrush of absolute tyrants.

We could venture into saying that the Aristotelian theoretical project of a perfect, autonomous and natural political sphere appears precisely when that idea was already doomed to disappear.

Facing this situation, Aristotle presents, in [6], two clearly conflicting conceptions of wealth. The first one was understood as "a number of instruments to be used in a household or in a polis” (paragraph 1256b); therefore this wealth was considered natural as long as limited.

Secondly, wealth was conceived as a large amount of money. Aristotle censured this belief of wealth since it was unnatural and unlimited. The latter is directly related to retail trade and to usury, and it is not virtuous, since "the quality of courage, for example, is not intended to make wealth, but to inspire confidence” (paragraph 1258a). Both conceptions of wealth set the atmosphere for the differentiation between natural and unnatural elements in the Stagirite's thought.

To understand how wealth is acquired, Aristotle begins his study on chrematistics, in [6], by telling the difference between chrematistics and oikonomía: "it is easy to see that the art of household management [oikonomía] is not identical with the art of getting wealth [chrematistics], for the one uses the material which the other provides. For the art which uses household stores can be no other than the art of household management” (paragraph 1256a).

Then, chrematistics is the factor which produces property, while oikonomía consists in the administration of that property. At the same time, Aristotle gives an account of two forms or definitions of chrematistics. Even though he uses multiple names to refer to each of them, the 'right' chrematistic is usually presented as household management or natural chrematistics, while the 'wrong' chrematistics is presented as unlimited or plain chrematistics. Anyhow, the philosopher includes chrematistics within the private sphere, given that it belongs to management and not to politics.

Natural chrematistics was aimed at providing those household goods which were, in a certain way, indispensable for bare life: "of the art of acquisition then there is one kind which by nature is a part of the management of a household, in so far as the art of household management must either find ready to hand, or itself provide, such things necessary to life, and useful for the community of the family or state, as can be stored. They are the elements of true riches; for the amount of property which is needed for a good life is not unlimited" (paragraph 1256b).

On the other hand, Aristotle introduces the 'wrong' chrematistics: "There is another variety of the art of acquisition which is commonly and rightly called an art of [chrematistics], and has in fact suggested the notion that riches and property have no limit. Others maintain that coined money is a mere sham, a thing not natural, but conventional only, because, if the users substitute another commodity for it, it is worthless, and because it is not useful as a means to any of the necessities of life" (paragraphs 1257a-b).

This kind of chrematistics differs considerably from the previous one in several aspects. While limited acquisition is natural, unlimited chrematistics comes from certain experience and art whose final outcome is retail trade and its resulting pursuit of profit.

Whereas exchange appears as bartering or involving money to obtain goods which are immediately unattainable other way, commerce does not exceed the self-sufficient sphere.

Consequently, it remains in the natural field. But when such activity gains in volume and the ambition to accumulate money expands, the nature of acquisition looses its path, leading into the unlimited aspect of chrematistics.

Deep down, this aspect of chrematistics is censured because it would bring with it a deepseated disdain for community in favour of particular interests. Then, what seems inconceivable is that the practice of such chrematistics deflects those who practice it from the true end of life, which is collective happiness and fulfilment, only attainable through politics.

To clarify this point, we should make a brief description of the four ways of exchange presented in [6] by Aristotle. In the first place, as we have seen, bartering is completely natural because it contributes to sufficiency. By sharing a common notion of commensurable value regardless currency, those involved in bartering exchange goods for other goods rather than for money. Then, "exchange with one another the necessaries of life and nothing more. [...] This sort of barter is not part of the wealth-getting art and is not contrary to nature, but is needed for the satisfaction of men's natural wants. The other or more complex form of exchange grew, as might have been inferred, out of the simpler. When the inhabitants of one state became more dependent on those of another, and they imported what they needed, and exported what they had too much of, money necessarily came into use” (paragraph 1257a). This means that currency appears to facilitate the exchange of perishable or geographically distant goods.

Therefore, the second form of exchange is introduced as a development of the previous one.

Here, the reciprocity process splits into two separate actions, buying and selling. The circuit of this form of exchange has a beginning and an end. In the market a good is sold for money; that money is used to buy another good. Once the needed good is obtained, acquisition comes to its end.

This second use becomes unavoidable, and leads to the third form of exchange. In this case, a man arrives at the market with money. He uses that money to buy a good, and then sells that good for more money. This form entails a great danger: 'wrong' chrematistics deflects those engaged in such practice from the reciprocity and sufficiency on which social life is based. Therefore, ¿ $i$ hat other argument but a moral one, could be used against those who, once made the profit, would not want to make it ad infinitum?

Finally, there is a forth form of exchange, marginally mentioned by the Stagirite. It entails pure usury, that is, the practice of lending money at a rate of interest. This form is logically loathed, given that "makes a gain out of 
money itself, and not from the natural object of it. For money was intended to be used in exchange, but not to increase at interest. And this term interest, which means the birth of money from money, is applied to the breeding of money because the offspring resembles the parent. Wherefore of all modes of getting wealth this is the most unnatural” (paragraph 1258b).

The previous analysis reveals that money was not considered naturally necessary. It appears as a response to historical needs of the polis. In view of the fact that men exchanged their goods for others, they eventually required the use of a device to facilitate that exchange. Aristotle turns currency into a conventional representation of necessity, as he discusses ethical points. In other words, necessity is the commensurable dimension, which has always existed and justifies bartering, and whose unit of currency is money. "For unless there is this proportion there cannot be exchange or dealing, and this proportion cannot be unless the terms are in some way equal; hence the need, as was stated above, of some one measure of all things. Now this is really and truly the necessity for them, which is the common bond of all such dealings. For if the parties were not in want at all or not similarly of one another's wares, there would either not be any exchange, or at least not the same. And money has come to be, by general agreement, a representative of necessity: and the account of its Greek name [nomisma] is this, that it is what it is not naturally but by custom or law [nomos], and it rests with us to change its value, or make it wholly useless" (paragraph 1133a). As we observe, in [4] money is the magnitude that represents necessity.

However, money does not have a value of its own (apart from the intrinsic value ascribed to the metal used to make the coins): "for it makes no difference whether you give for a house five beds or the price of five beds" (paragraph 1133b).

In Ethics, Aristotle defends the idea that the price, though conventional, should be set by the buyer of the good, since he will really use it to fulfil the end upon which that good has been created.

This is why in [4] friendship is a core category that cuts through the entire matter. When friendships are between dissimilar men, "it is the proportion which equalizes and preserves the friendship". In political friendship, "a common measure has been provided in money, and to this accordingly all things are referred and by this are measured: but in the friendship of love the complaint is sometimes from the lover that, though he loves exceedingly, his love is not requited" (paragraphs 1163b1164a).

In this same sense, in Ethics, Aristotle told the story of the lyre-player to whom a man promised a higher reward if he performed his best in his interpretation. When the lyre- player finished playing, he asked for more money. But instead of receiving more money he was told that his reward was the pleasure of doing things in its best way.

Then, for Aristotle, price is a convention independent from money. As a matter of fact, it is a private arrangement between those involved in the transaction. That is why we can observe that the notion of gift lies in the origin of exchange. We are now able to contemplate why, all things considered, money has to move in the realms where gift is no longer possible. In view of that, we should analyze two moral virtues which associate the citizen to the use of money very intimately. We have mentioned them before, when we discussed the sense of exchange in the classical Greek perspective. When Greek aristocracy achieved its greater splendour, the wealthiest citizens were asked to pay for many of the public activities of the polis, such as sacrifices, festivals, armaments, etc. Sometimes they were requested by the government, sometimes they acted on their own initiative as a way of gaining popularity.

Liberality, as well as magnificence, was the kind of virtue that could only be practiced by the wealthiest. The liberal man was praised for his way of giving in regard to those things whose value was measured in money. The name given to this virtue points out a certain obligation of the free men to be generous to the polis. The noble thing about the liberal was the fact that he did not pay attention to himself but to the others (the friends), when spending money. He acted out of love to his fellow-citizens, not out of charity. "The things that have a use may be used either well or badly; and riches is a useful thing; and everything is used best by the man who has the virtue concerned within; and this is the liberal man. Now spending and giving seem to be the using of wealth; taking and keeping rather the possession of it” (paragraph 1120a).

On the other hand, magnificence was the action of spending properly but on a large scale. When did a citizen spend appropriately? "Magnificence is an attribute of expenditures of the kind which we call honourable, e.g. those connected with the gods-votive offerings, buildings, and sacrifices and similarly with any form of religious worship, and all those that are proper objects of publicspirited ambition” (paragraph 1122b). By means of such argument, Aristotle gives -whether intentionally or not- a glimpse of the intimate relation between the monetary and the sacred domains.

What is the point of highlighting two aristocratic virtues which were no longer frequent in the democratic context? Aristotle does not intend to go back to a previous time; quite the opposite, he wants to emphasize that the importance of money is in its use and not in the generation of profit. Then, he reintroduces the strong separation between the human life, as long as political, within the polis, and the not human existence, outside the polis and outside the sphere of use. In the case of money, the problem is that "we all love it to a large o lesser degree", and hence its use should be regulated.

Aristotle conceived the world as a naturally hierarchical structure. Family was the community which existed to fulfil men's bare needs, whereas politeia was the realm for the realization of the good life, of happiness. Deep down, the polis is logically prior to each individual and it is perfect because it achieves autarchy. It is the minimum self-sufficient human unit.

Gods are above men, and given its natural selfsufficiency they do not live in the polis. In this regard, Aristotle said: "Will not the gods seem absurd if they make contracts and return deposits, and so on?”, and continues: "It will be strange if they are really to have money", given that, "For self-sufficiency and action do not involve excess” (paragraph 1178b).

Politically speaking again, in [6], it is desirable for citizens to live in similar conditions, hoping to attain to the happy medium, and to pull riches and poverty apart from the polis: "it is not the possessions but the desires of 
mankind which require to be equalized" (paragraph 1266b).

Aristotle mentions that in democratic polis, "the demagogues of our own day often get property confiscated in the law-courts in order to please the people. Thus, those who have the welfare of the state at heart should counteract them, and make a law that the property of the condemned should not be public and go into the treasury, but be sacred” (paragraph 1320a). The word hierós (sacred) appears in the quotation. Regarding the requisitioned goods as sacred reflects the exact place where the distinction between the religious and the profane becomes blurred in Greek penal law.

As Agamben states, the things that belonged to the gods were sacred or religious. As such, they were removed from the commerce and the retail trade. They could not be borrowed, transferred, levied or fined. In other words, the main effect of regarding goods as sacred was its separation from human use.

What was the purpose of turning certain goods into unavailable ones? A thorough analysis allows us to observe that the grounds of such imposition were to punish offenses against public matters.

The most effective way to avoid the perpetration of other (and more serious) offenses with those confiscated goods (such as the use of money for particular purposes) was the removal of ill-gotten goods from the men's sphere by making its usufruct impossible.

\section{Conclusions}

Let's sum up. As it was pointed out in the beginning of this presentation, Benveniste has proved that the religious root of all economic conceptions is a characteristic feature shared by the Indo-European nucleus. It also follows from his studies that the main ambivalence between the human and the sacred appears as the distinction between the things which can be used by men and those banned from their use. In this sense, the fundamental distinction between hierós (sacred) and hósios (profane) lies in the unavailability of the goods which are considered divine.

Agamben, in [7] argues that while consecration put things aside human law, profanation implies its return to the use of men. By means of this logic, unlimited chrematistics constitutes the main act of regarding money as sacred, given that its practice took money off the sphere of use (for its end is accumulation). But the fact that those who practiced chrematistics were withdrawn from the political activity is even more serious. Their compulsion to accumulate money removed liberty and leisure from them, only to lock them up in the sphere of the household.

Aristotle condemns unlimited chrematistics because its practice entailed the pre-eminence of particular interests (profit) against the true fulfilment of the zoon politikon through politics. In this regard, it is relevant to observe the example given by Aristotle in Politics, VI, when, referring to the democracy of an agricultural population, he states that "being poor, they have no leisure, and therefore do not often attend the assembly, and not having the necessaries of life they are always at work, and do not covet the property of others. Indeed, they find their employment more pleasant than the cares of government" (paragraph 1318b). This is the danger of unlimited chrematistics.

It is usually disregarded that Aristotle was not nostalgically defending the notion of gift, but trying to reconcile that logic to the inescapable use of money. His attempt to maintain the harmony of the polis was related to the preservation of the fairness in the exchanges mediated by money. The Aristotelian question was not as much melancholic as it was the establishment (or maybe re-establishment) of a political realm. More specifically, his interest was to regulate the social practices in which the use of money was unavoidable. In other words, Aristotle tried to resolve the question of how could men use money in exchange processes without being under its thumb. This problem persists up to our times.

\section{References}

[1] AgAmBen, G. Homo Sacer I. Sovereign Power and Bare Life. Stanford University Press. 1998.

[2] AGAMBEN, G. Il Regno e la Gloria. Neri Pozza, Vicenza, 2007.

[3] BENVENISTE, É. Le Vocabularie des Institutions IndoEuropéenes. Minuit. Paris, 1969.

[4] ARISTOTLE. Nicomachean Ethics. The Complete Works of Aristotle. Vol. 2. Ed. Jonathan Barnes. Princeton, Princeton University Press, 1991.

[5] POLANYI, K. "Aristotle discovers the economy". In Polanyi, Arensberg \& Pearson (Eds.). Trade and market in the early empires: economies in history and theory. The Free Press. Glencoe, 1957.

[6] ARISTOTLE. Politics. The Complete Works of Aristotle. Vol. 2. Ed. Jonathan Barnes. Princeton, Princeton University Press, 1991.

[7] AGAMBEN, G. Profanazioni. Nottetempo. Roma, 2005. 